\title{
Reproductive toxicity of acetamiprid in male Guinea pig (Cavia porcellus)
}

\author{
Augustave Kenfack, Arthénice Jemima Nounamo Guiekep*, Ferdinand Ngoula, Bertin \\ Narcisse Vemo, Freddy Patrick Ngah Osoe Bouli, Etienne Tedonkeng Pamo
}

\author{
${ }^{1}$ University of Dschang, Faculty of Agronomy and Agricultural Sciences, Department of Animal Sciences, P. O. Box 188 \\ Dschang, Cameroon. \\ *Corresponding author. Email: jnounamo@yahoo.fr. Tel.: +237 676267540.
}

\begin{abstract}
Copyright @ 2018 Kenfack et al. This article remains permanently open access under the terms of the Creative Commons Attribution License 4.0,
\end{abstract} which permits unrestricted use, distribution, and reproduction in any medium, provided the original work is properly cited.

Received 26th May, 2018; Accepted 22nd June, 2018

\begin{abstract}
The neonicotinoid insecticides including acetamiprid are widely used in pest-control programs due to their high efficacy and low cost. This study aimed to investigate the impact of acetamiprid on reproductive parameters as well as its ability to generate oxidative stress in male guinea pig. Twenty-four adult male guinea pigs received oral administration of distilled water (control) and 3 different doses (26.67, 40 and $80 \mathrm{mg} / \mathrm{kg}$ body weight) of acetamiprid during 90 days. The effects of treatments were studied on some reproductive toxicity parameters and oxidative stress makers. Results showed that the administration of acetamiprid led to a significant $(P<0.05)$ decrease in the testosterone concentration, reproductive organs weights, sperm count, sperm mobility, plasma membrane integrity, reaction time and a significant $(P<0.05)$ increase of abnormal spermatozoa. Malondialdehyde and catalase activities increased significantly $(P<0.05)$ in animals receiving acetamiprid. Reduced glutathione decreased significantly $(P<0.05)$ in acetamiprid-treated animals while superoxide dismutase activity showed a significantly $(P<0.05)$ higher value in animals receiving the highest dose of insecticide with reference to the control group. Moreover, acetamiprid-treated animals showed the presence of some immature germinal cells in the lumen of the seminiferous tubules compared to the control. In conclusion, results obtained in the current study revealed that acetamiprid caused perturbations on male reproductive system and induced oxidative stress.
\end{abstract}

Keywords: Acetamiprid, male guinea pig, oxidative stress, reproduction toxicity.

\section{INTRODUCTION}

Large numbers of agrochemicals are increasingly used in agricultural farm lands, animal husbandry as well as in public health operations to kill insects, weeds and to get rid of insect transmitted diseases (Mondal et al., 2014; Mohamed et al., 2015; Turkyilmaz and Dereboylu, 2015). Unfortunately, their intensive usage raised concerns about hazards on human and animal health (Swan et al., 2003; Gu et al., 2013). Among much used agrochemicals are pesticides like organophosphates, carbamates, pyrethroids and neonicotinoids.

Neonicotinoids are a new class of insecticides occupying a dominant position in global market (Gibbons et al., 2014; Ivert, 2016). They have outstanding potency and systemic action for crop protection against piercing-sucking insects (Mondal et al., 2009) and they are highly effective for flea control (Goulson, 2013). These insecticides are grouped into two types: N-nitroguanidines (imidacloprid, thiamethoxam, dinotefuran and clothianidin) and $\mathrm{N}$ cyanoamidines (acetamiprid and thiacloprid). They are nicotinic acetylcholine receptor agonists; they bind strongly to insects' nicotinic acetylcholine receptors in the central nervous system and cause paralysis and even death (Bansal and Chaudry, 2011; Laurino et al., 2011). Even though neonicotinoids are more toxic to insects than mammals (Jeschke and Nauen, 2008), an increasing number of cases of these insecticides poisoning in 
mammals have been reported in recent years (Kapoor et al., 2011; Bal et al., 2012). They are cardiotoxicity and neurotoxicity (Keshta et al., 2016), histopathological and biochemical alterations (Mondal et al., 2014), oxidative and reproductive toxicity (Kapoor et al., 2011; Gu et al., 2013; Keshta et al., 2016).

Acetamiprid (ACP) is a systemic and contact insecticide. It is widely used in floriculture on leafy vegetables, cole crops, citrus, cotton, ornamentals, and fruiting vegetables (Tomizawa and Casida, 2005). Widespread use of ACP is causing pesticide entry into the food chain which in turn causes toxicity to man and animal, including reproductive safety (Mondal et al., 2014). Thus, some studies have reported ACP exposure to have adverse effects on animal blood profile, biochemical parameters, sperm count and mobility and testosterone level (Mahmoud, 2011; Singh et al., 2012; Gu et al., 2013; Mosbah et al., 2017). Moreover, acetamiprid may exert effect through oxidative stress (Keshta et al., 2016). Meanwhile, little information is available on its reproductive toxicity. Therefore, the present study was undertaken to evaluate the toxicity of acetamiprid on the reproductive function as well as its potential to generate oxidative stress in male guinea pig.

\section{MATERIALS AND METHODS}

\section{Animals and lodging}

Twenty-four adult male Guinea-pigs aged 4 months and of average weight $410.87 \pm 68.06 \mathrm{~g}$ from the Teaching and Research Farm of the University of Dschang were used. They were housed in cages at room temperature, with 12 hours day light/dark cycle. They were handled according to ethical guidelines of the Cameroonian National Veterinary Laboratory.

\section{Feeding and pesticide}

Animals were fed with elephant grass-based ration and a supplement of compound feed. Acetamiprid $20 \%$ water soluble, light blue, fine powder commercially called OPTIMAL 20 SP was purchased from the Louis Dreyfus Commodities Society, Cameroon, found in the industrial zone of Bonaberi-Douala. The doses used were 0.00, 26.67, 40 and $80 \mathrm{mg} / \mathrm{kg}$ body weight (bw).

\section{Trial conduct}

The animals were identified with earrings. They were randomly distributed into 4 groups (G1, G2, G3 and G4) of 6 animals. During 90 days, animals of $G 1$ orally received distilled water (control) while those of G2, G3 and G4 received 26.67, 40 and $80 \mathrm{mg} / \mathrm{kg}$ bw of acetamiprid respectively. The animal body weight was recorded weekly and the doses of pesticides adjusted accordingly.

\section{Studied parameters and data collection}

\section{Reaction time}

Each experimental animal was housed with an adult female, and the time taken for the male to attempt the mount was noted. The maximum observation time was 5 minutes.

\section{Sexual organs weight and sperm characteristics}

Animals were weighed with the help of a scale with capacity $160 \mathrm{~g}$ and precision $10^{-3} \mathrm{~g}$. At the end of the treatment they were anesthetised using ether vapour. They were then dissected and organs (testes, epididymides, vas deferens, and accessory glands) were removed and weighed. The relative organs weight was calculated using the formula below:

Relative organs weight $=\frac{\text { Weight of organ }}{\text { Live weight of animal }} \times 100$

The cauda epididymides were minced in $5 \mathrm{ml}$ of $0.9 \% \mathrm{NaCl}$ solution (at $37^{\circ} \mathrm{C}$ ) for sperm concentration, mobility, integrity and morphology evaluation. For sperm mobility, a drop of the obtained solution was placed on a slide and observed under the microscope and the mobility score was attributed according to Baril et al. (1993), using a scale from 0 to 5 . The sperm count was done using the Thoma haemocytometer, while sperm morphological abnormalities (small and big heads, coiled tails) and the integrity of the plasma membrane were evaluated using an eosin-nigrosin solution and the hypo-osmotic test (KumiDiaka, 1993) respectively.

\section{Serum testosterone concentration}

Blood was collected by cardiac puncture and used to obtain the serum. The serum content in testosterone was quantified using ELISA method, according to the instructions of Omega Diagnostics kit (Scotland, United Kingdom).

\section{Oxidative stress}

A $15 \%$ (W/V) homogenate was prepared using the left testis of each animal. Thus, the testis was crushed in $0.9 \%$ $\mathrm{NaCl}$ followed by a centrifugation (3000 rpm, $30 \mathrm{~min})$ and the supernatant was used for biochemical analyses. The determination of malondialdehyde concentration was done by the thiobarbituric acid method of Nilsson et al. (1989), while the superoxide dismustase activity was evaluated according to Misra and Fridovich (1972). The catalase activity was assessed using the chromic acetate method as described by Sinha (1972) and the concentration of 


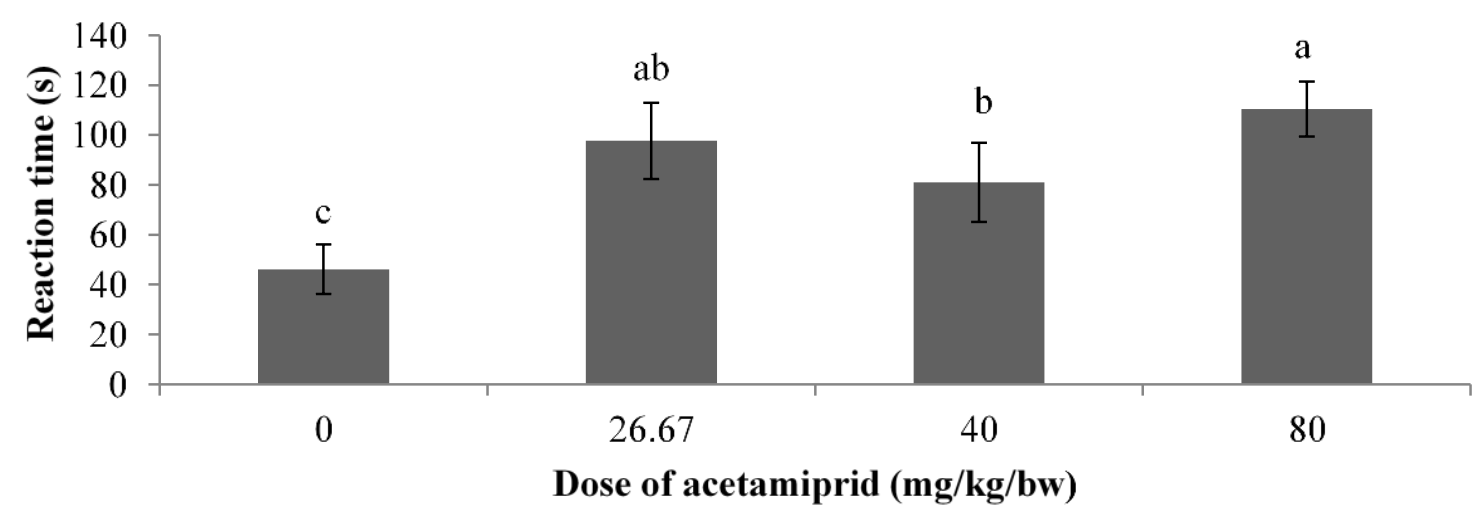

Figure 1. Variation of the reaction time according to the doses of acetamiprid. a,b,c; Bars with the same letters are not significantly $(P>0.05)$ different.

Table 1. Effects of acetamiprid on reproductive organs weight in male guinea pig.

\begin{tabular}{lccccc}
\hline \multirow{2}{*}{ Organs $(\mathbf{g} / \mathbf{1 0 0} \mathbf{g}$ of $\mathbf{~ b w )}$ Doses of acetamiprid $\mathbf{~} \mathbf{g} / \mathbf{k g} / \mathbf{b w}$} \\
\cline { 2 - 6 } & $\mathbf{0}$ (control) $\mathbf{(} \mathbf{n} \mathbf{6})$ & $\mathbf{2 6 . 6 7}(\mathbf{n}=\mathbf{6})$ & $\mathbf{4 0}(\mathbf{n}=\mathbf{6})$ & $\mathbf{8 0}(\mathbf{n}=\mathbf{6})$ & $\mathbf{P}$ \\
\hline Testes & $0.23 \pm 0.01$ & $0.20 \pm 0.06$ & $0.21 \pm 0.02$ & $0.21 \pm 0.03$ & 0.38 \\
Epididymides & $0.09 \pm 0.01$ & $0.08 \pm 0.02$ & $0.08 \pm 0.01$ & $0.07 \pm 0.02$ & 0.31 \\
Vas deferens & $0.06 \pm 0.01$ & $0.04 \pm 0.02$ & $0.04 \pm 0.02$ & $0.04 \pm 0.01$ & 0.26 \\
Accessory glands & $0.43 \pm 0.09^{\mathrm{a}}$ & $0.22 \pm 0.07^{\mathrm{b}}$ & $0.23 \pm 0.08^{\mathrm{b}}$ & $0.25 \pm 0.06^{\mathrm{b}}$ & 0.00 \\
\hline
\end{tabular}

a,b: Within the same line, numbers with the same letters are not significantly $(P>0.05)$ different; $P$ : probability; $n$ : number of guinea pigs; bw: body weight.

reduced glutathione was determined by the potassium iodate method of Habbu et al. (2008).

\section{Histological analysis}

The right testis was fixed in $10 \%$ formol solution, and then washed, dehydrated with ascending grade of alcohol bath, clarified in xylene immersion, embedded in paraffin, sectioned at $5 \mu \mathrm{m}$ and stained with haematoxylin and eosin. The tissue sections were observed under a light microscope (400 x magnifications).

\section{Statistical analysis}

Results were expressed as mean \pm standard deviation. Differences between groups were assessed using oneway ANOVA followed by the Duncan's test at $5 \%$ significance. All the analyses were performed using the SPSS 20.0 software.

\section{RESULTS}

\section{Reaction time}

The reaction time (Figure 1) was significantly $(P<0.05)$ longer in animals treated with acetamiprid compared to the control.

\section{Reproductive organs weight}

The relative weights of the testes, epididymides, vas deferens and accessory glands (Table 1) decreased in animals exposed to acetamiprid compared to the control. However, the significant $(P<0.05)$ difference between treated and control groups was observed only for the weight of accessory glands.

\section{Epididymal sperm characteristics}

The mobility, number of spermatozoa per tail and per gram of epididymis and membrane integrity of spermatozoa (Table 2) significantly $(\mathrm{P}<0.05)$ reduced in guinea pigs force-fed with acetamiprid with reference to the control group. Meanwhile, the percentage of abnormal spermatozoa (with big and small heads) increased significantly $(P<0.05)$ in insecticide-treated animals with respect to the control. Whereas some few spermatozoa with coiled tails were observed only in the group of animals treated with the highest dose of acetamiprid. 
Table 2. Effects of acetamiprid on characteristics of cauda epididymal spermatozoa.

\begin{tabular}{lccccc}
\hline \multirow{2}{*}{$\begin{array}{l}\text { Cauda epididymal sperm } \\
\text { characteristics }\end{array}$} & \multicolumn{5}{c}{ Doses of acetamiprid $\mathbf{~ g / k g / b w}$} \\
\cline { 2 - 6 } & $\mathbf{0 ( c o n t r o l ) ( \mathbf { n } = \mathbf { 6 } )}$ & $\mathbf{2 6 . 6 7}(\mathbf{n}=\mathbf{6})$ & $\mathbf{4 0}(\mathbf{n}=\mathbf{6})$ & $\mathbf{8 0}(\mathbf{n}=\mathbf{6})$ & $\mathbf{P}$ \\
\hline Mobility $(\%)$ & $90.00 \pm 5.35^{\mathrm{a}}$ & $80.00 \pm 7.07^{\mathrm{ab}}$ & $70.00 \pm 15.81^{\mathrm{b}}$ & $70.00 \pm 14.14^{\mathrm{b}}$ & 0.01 \\
Number/cauda $\left(\times 10^{7}\right)$ & $6.00 \pm 1.90^{\mathrm{a}}$ & $3.35 \pm 0.72^{\mathrm{b}}$ & $3.70 \pm 1.41^{\mathrm{b}}$ & $3.88 \pm 1.88^{\mathrm{b}}$ & 0.03 \\
Number/g $\left(\mathrm{x} 10^{7}\right)$ & $25.20 \pm 5.40^{\mathrm{a}}$ & $16.93 \pm 5.80^{\mathrm{b}}$ & $18.21 \pm 3.58^{\mathrm{b}}$ & $21.66 \pm 4.12^{\mathrm{ab}}$ & 0.03 \\
Spermatozoa with IPM (\%) & $78.88 \pm 5.62^{\mathrm{a}}$ & $69.80 \pm 3.27^{\mathrm{b}}$ & $59.00 \pm 4.18^{\mathrm{c}}$ & $56.50 \pm 3.87^{\mathrm{c}}$ & 0.00 \\
Big and small heads (\%) & $5.25 \pm 1.75^{\mathrm{c}}$ & $9.60 \pm 2.07^{\mathrm{b}}$ & $9.20 \pm 2.28^{\mathrm{b}}$ & $14.00 \pm 2.94^{\mathrm{a}}$ & 0.00 \\
Coiled tail $(\%)$ & $0.00 \pm 0.00$ & $0.00 \pm 0.00$ & $0.00 \pm 0.00$ & $0.25 \pm 0.50$ & 0.22 \\
\hline
\end{tabular}

a,b,c: Within the same line, numbers with the same letters are not significantly $(P>0.05)$ different; $P$ : probability; IPM: integral plasma membrane; $n$ : number of guinea pigs; bw: body weight.

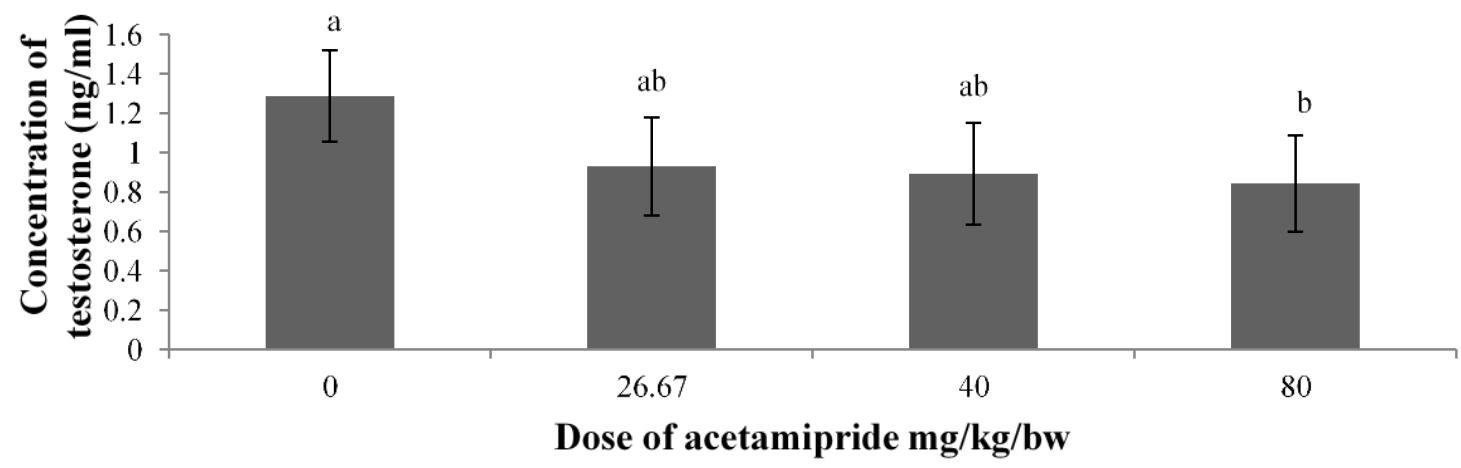

Figure 2. Variation of the concentration of testosterone according to the doses of acetamiprid. a,b: Bars with the same letters are not significantly $(P>0.05)$ different.

Table 3. Effect of acetamiprid on indicators of oxidative stress.

\begin{tabular}{lccccc}
\hline \multirow{2}{*}{ Indicators of oxidative stress } & \multicolumn{5}{c}{ Doses of acetamiprid $\mathbf{~ g} \mathbf{g} \mathbf{k g} / \mathbf{b w}$} \\
\cline { 2 - 6 } & $\mathbf{0}$ (control) $(\mathbf{n}=\mathbf{6})$ & $\mathbf{2 6 . 6 7}(\mathbf{n}=\mathbf{6})$ & $\mathbf{4 0}(\mathbf{n}=\mathbf{6})$ & $\mathbf{8 0}(\mathbf{n}=\mathbf{6})$ & $\mathbf{P}$ \\
\hline MDA $(\mu \mathrm{M} / \mathrm{g}$ of testis) & $38.12 \pm 8.79^{\mathrm{b}}$ & $58.27 \pm 5.29^{\mathrm{a}}$ & $60.42 \pm 7.66^{\mathrm{a}}$ & $53.07 \pm 8.15^{\mathrm{a}}$ & 0.00 \\
$\mathrm{GSH}(\mu \mathrm{M} / \mathrm{g}$ of testis) & $558.24 \pm 62.01^{\mathrm{a}}$ & $454.90 \pm 87.28^{\mathrm{b}}$ & $438.43 \pm 76.94^{\mathrm{b}}$ & $415.83 \pm 59.70^{\mathrm{b}}$ & 0.04 \\
$\mathrm{CAT}(\mu \mathrm{mol} / \mathrm{min} / \mathrm{g}$ of testis) & $16.88 \pm 1.92^{\mathrm{b}}$ & $22.92 \pm 1.80^{\mathrm{a}}$ & $21.21 \pm 3.36^{\mathrm{a}}$ & $23.04 \pm 2.53^{\mathrm{a}}$ & 0.00 \\
SOD $(\mathrm{U} / \mathrm{mg}$ of testicular protein) & $12.90 \pm 3.76^{\mathrm{b}}$ & $16.85 \pm 3.27^{\mathrm{b}}$ & $19.41 \pm 4.98^{\mathrm{b}}$ & $27.76 \pm 6.39^{\mathrm{a}}$ & 0.01 \\
\hline
\end{tabular}

a,b: Within the same line, numbers with the same letters are not significantly $(P>0.05)$ different; $P$ : probability; $n$ : number of guinea pigs; bw: body weight. MDA: malondialdehyde, GSH: reduced glutathione levels, CAT: catalase and SOD: superoxide dismutase.

\section{Testosterone concentration}

The serum concentration of testosterone (Figure 2) decreased with an increasing dose of acetamiprid. However, only guinea pigs treated with the highest dose (80 mg/kg body weight) showed a significant $(P<0.05)$ difference compared to the control.

\section{Indicators of oxidative stress}

In Table 3, the concentration of malondialdehyde (MDA) and the activities of catalase (CAT) and superoxide dismutase (SOD) generally increased significantly $(P<0.05)$ in acetamiprid-treated animals compared to the control. The contrary was observed for the concentration of reduced glutathione (GSH).

\section{Histopathology}

In Figure 3, the histological section of the testis in the control group $\left(T_{0}\right)$ showed a normal structure with the seminiferous epithelium containing all generations of 

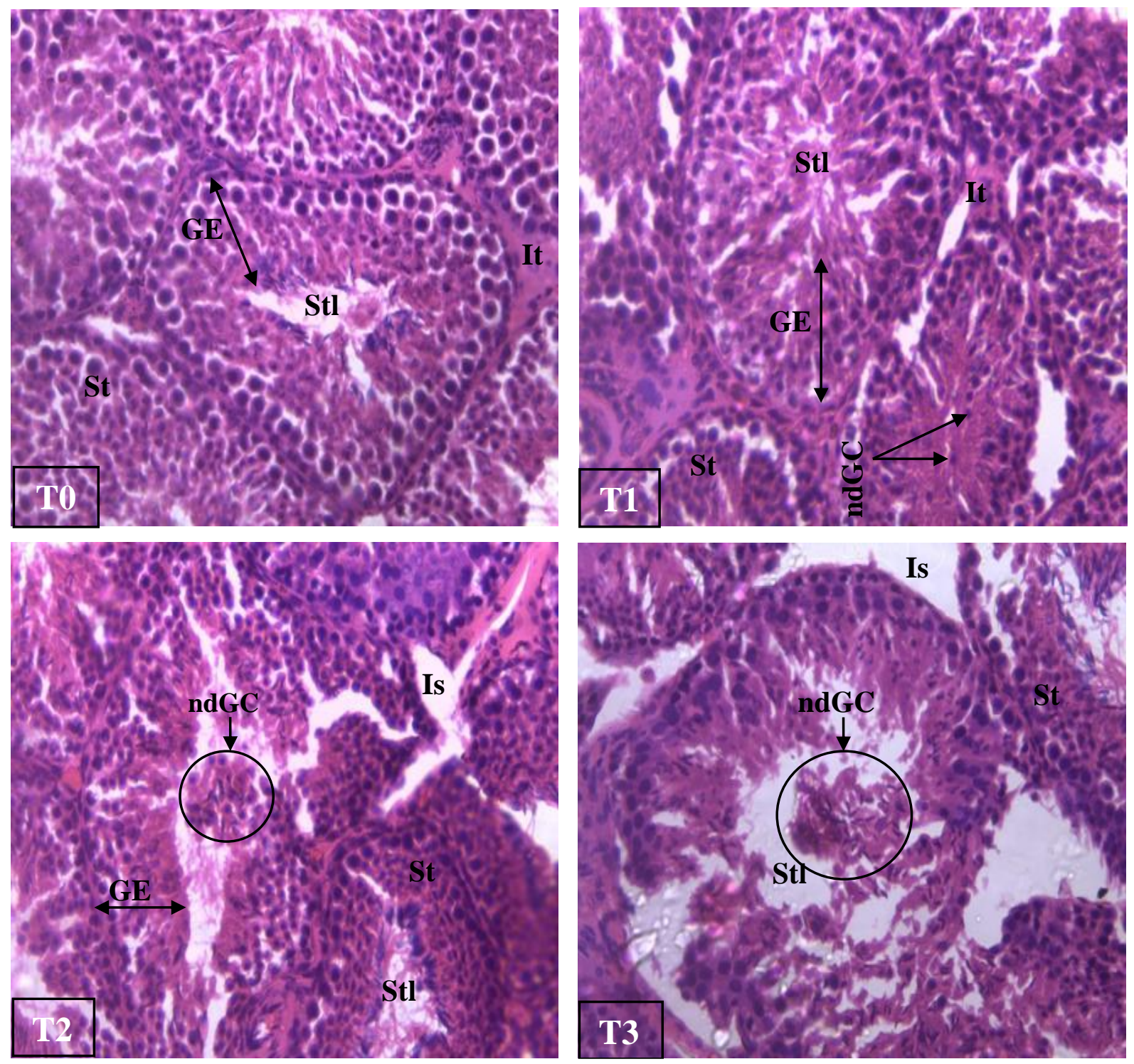

Figure 3: Testis histological sections of guinea pigs exposed to acetamiprid (HE x 400). ndGC: non differentiated germinal cells; Is: interstitial space; It: interstitial tissue; Stl: seminiferous tubule lumen; St: seminiferous tubule; GE: germinal epithelium; T0: control; T1: guinea pigs treated with $26.67 \mathrm{mg} / \mathrm{kg}$; T2: guinea pigs gavaged with 40 $\mathrm{mg} / \mathrm{kg}$; T3: guinea pigs treated with $80 \mathrm{mg} / \mathrm{kg}$ body weight.

germinal cells and normal flagellated spermatozoa in the lumen. The group treated with the smallest dose $\left(T_{1}\right)$ of acetamiprid unveiled the presence of few non differentiated germinal cells in the lumen. However, a pile of non-differentiated cells was present in the lumen of guinea pigs treated with highest doses $\left(T_{2}\right.$ and $\left.T_{3}\right)$. In addition, in guinea pigs given the highest doses of the pesticide, the interstitial tissue was markedly destroyed.

\section{DISCUSSION}

Despite the lower affinity to mammalian nicotinic acetylcholine receptors, neonicotinoid pesticides have been shown to cause toxicity when they accumulate within body organs (Kapoor et al., 2010; Bal et al., 2012; Gu et al., 2013). In the present study, the administration of acetamiprid reduced the weight of testes, epididymis, vas deferens and accessory glands. Similar decrease was observed by Zhang (2011) and Mosbah et al. (2017) in mice and rats treated with acetamiprid. Decrease in testicular weight could be associated to the decrease in the number of germ cells since the latter represent an important part of male gonad in mammals (Nicolino and Forest, 2001). Moreover, this diminution could equally be attributed to the decrease in testosterone production. In fact, low serum testosterone levels have been reported to negatively affect the weight of testes (Mooradian et al., 
1997). Since the development of the male reproductive organs is under the hormonal control of the testes, the weight of the epididymis, vas deferens and accessory glands were affected accordingly. The presence of immature germinal cells in the seminiferous tubule lumen of acetamiprid-exposed guinea pigs might be due to an exfoliation of non-differentiated germinal cells, which could have then affected the weight of testes.

Sperm count, mobility and morphology are considered to be important factors that affect fertility (Kobeasy et al., 2015). Results obtained from this work showing a decrease in sperm count, mobility and membrane integrity but an increase in the percentage of abnormal spermatozoa. This agrees with the works of Mosbah et al. (2017) in rats treated with acetamiprid. The decrease in sperm quality could be a result of the plasma membrane disintegration following the over production of reactive oxygen species (ROS) induced by acetamiprid. In fact, spermatozoa are vulnerable to ROS because their plasma membrane contains large amounts of polyunsaturated fatty acids (Agarwal et al., 2003). Thus, excessive generation of ROS in semen by leukocytes as well as by abnormal spermatozoa could be a cause of the low sperm quality (Agarwal et al., 2003). Besides, testicular size is a good indicator of sperm number (Singer, 2005). Therefore, spermatozoa characteristics obtained are inherent to the reduction in the weight of sex organs. Moreover, recent reports (Umar et al., 2012; El-Neweshy et al., 2013; Kobeasy et al., 2015) suggested that exposure to pesticides increase sperm abnormalities which could be related to low levels of serum testosterone as it is the case in this study.

The decrease in testosterone concentration in animals treated with acetamiprid was predictable, because there is a positive relationship between testosterone production and testicular development. This result agrees with those of Kenfack et al. (2007), Ngoula et al. (2007) and Kong et al. (2017) in rats exposed to chlorpyriphos-ethyl, pyrimiphos-methyl and acetamiprid respectively. This diminution in testosterone concentration consequently led to a decrease in the libido of males. In fact, male sexual behaviour in vertebrate species is dependent on testosterone production (Wang et al., 2000; Neave and O'Connor, 2009).

The present study showed that acetamiprid caused an increase in the levels of MDA, CAT, SOD and a decrease in the concentration of GSH. This observation is in agreement with the results of Agarwal and Sharma (2010) in rats treated with carbofuran. MDA is an important indicator of oxidative stress in cells (Mansour and Mossa, 2010; Badade and Samant, 2011). Thus, its increase might be explained by the fact that the action of acetamiprid induced the oxidation of polyunsaturated fatty acid and therefore could equally explain the concomitant decrease in the level of GSH which intervene in the degradation of MDA. SOD and CAT constitute the first line of defence against reactive oxygen species. They are useful in the prediction of sperm fertilizing potentials (Badade and Samant, 2011). Therefore, the increase in oxidative stress parameters could be due to free radicals generated by acetamiprid intoxication.

\section{Conclusion}

The administration of acetamiprid to male guinea pigs during 90 days induced the reduction of the weight of the testes, epididymides, vas deferens and accessory glands. The epididymal sperm characteristics, reaction time, testosterone concentration and structure of the testes were negatively affected. It generated oxidative stress characterised by the increase in the testicular concentration of malondialdehyde, the activities of catalase and superoxide dismutase and a decrease in the testicular concentration of reduced gluthatione.

\section{CONFLICT OF INTEREST}

The authors declare that they have no conflict of interest.

\section{REFERENCES}

Agarwal, A., \& Sharma, B. (2010). Pesticides induced oxidative stress in mammalian systems: A review. International journal of biological and medical research, 1, 90-104.

Agarwal, A., Saleh, R. A., \& Bedaiwy, M.A. (2003). Role of reactive oxygen species in the pathophysiology of human reproduction. Fertility and Sterility, 79(4), 829-843.

Badade, Z. G., \& Samant, P. M. (2011). Role of Oxidative Stress in Male Infertility. Journal of Biomedical Science and Research, 3(2), 385-391.

Bal, R., Türk, G., Yılmaz, Ö., Etem, E., Kuloğlu, T., Baydaş, G., \& Naziroğlu, M. (2012). Effects of clothianidin exposure on sperm quality, testicular apoptosis and fatty acid composition in developing male rats. Cell Biology and Toxicology, 28, 187200.

Bansal, M., \& Chaudhry, A. (2011). Evaluation of mutagenic potential of acetamiprid by dominant lethal test on Culex quinquefasciatus. Journal of Applied and Natural Science, 3 (2), 171-175.

Baril, G., Chemineau, P., Cognie, Y., Guerin, Y., Leboeuf, B., Orgeur, P., \& Vallet, C. J. (1993). Manuel de formation pour l'insémination artificielle chez les ovins et les caprins. FAO. Station de la physiologie de la reproduction institut national de la recherche agronomique (INRA), No. 83, 125p.

El-Neweshy, M. S., El-Maddawy, Z. K., \& El-Sayed, Y. S. (2013). Therapeutic effects of date palm (Phoenix dactylifera L.) pollen extract on cadmium-induced testicular toxicity. Andrologia, 45(6), 369-378.

Gibbons, D., Morrissey, C., \& Mineau, P. (2014). A review of the direct and indirect effects of neonicotinoids and fipronil on vertebrate wildlife. Environmental Science and Pollution Research International, 16p.

Goulson, D. (2013). An overview of the environmental risks posed by neonicotinoid insecticides. Journal of Applied Ecology, 50(4), 977-987. 
Gu, Y., Li, Y., Huang, X., Zheng, J., Yang, J., Diao, H., Yuan, Y., Xu, Y., Liu, M., Shi, H., \& Xu, W. (2013). Reproductive effects of two neonicotinoid insecticides on mouse sperm function and early embryonic development In vitro. PLoS One, 8(7), 1-7.

Habbu, P. V., Shastry, R. A., Mahadevan, K. M., Hanumanthachar, J., \& Das, S. K. (2008). Hepatoprotective and antioxidant effects of argyreia speciosa in rats. African Journal Traditional Complementary and Alternative Medicines, 5(2), 158-164.

Ivert, M. (2016). toxicité des néoniconinoïdes chez l'abeille domestique. Thèse de Doctorat en Médecine vétérinaire, Campus vétérinaire de lyon: Université Claude-Bernard-LYON I, Pp. 1-88.

Jeschke, P., \& Nauen, R. (2008). Neonicotinoids from zero to hero in insecticide chemistry. Pest Management Science, 64(11), 1084-1098.

Kapoor, U., Srivasta, M. K., \& Srivasta, L. P. (2011). Toxicological impact of technical imidacloprid on ovarian morphology, hormones and antioxidant enzymes in female rats. Food and Chemical Toxicology, 49, 3086-3089.

Kenfack, A., Watcho, P., Ngoula, F., Tchoumboue, J., \& Kamtchouing, P. (2007). Influence du chorpyriphos-ethyl sur quelques paramètres de reproduction chez le rat mâle albinos exposé pendant le développement post natal. International Journal of Biological and Chemical Sciences, 1(3), 237-243.

Keshta, A. T., Hataba, A. A., Mead, H. M. I., \& El-Shafey, M. N. (2016). Oxidative stress and biochemical changes induced by thiamethoxam and acetamiprid insecticides in rats. World Journal of Pharmacy and Pharmaceutical Science, 5(6), 44-60.

Kobeasy, M. I., El-Naggar, A. Y., \& Abdallah, A. A. (2015). A novel methods for protective role against reproductive toxicity of carbofuren in male rats using palm pollen grains and vanadyl(II) folate as a new compound. Journal of Chemical and Pharmaceutical Research, 7(4), 1142-1148.

Kong, D., Zhang, J., Hou, X., Zhang, S., Tan, J., Chen, Y., Yang, W., Zeng, J., Han, Y., Liu, X., Xu, D., \& Cai, R. (2017). Acetamiprid inhibits testosterone synthesis by affecting the mitochondrial function and cytoplasmic adenosine triphosphate production in rat Leydig cells. Biology of Reproduction, 96(1), 254-265.

Kumi-Diaka, J. (1993). Subjecting canine semen to the hypoosmotic test. Theriogenology, 39(6), 1279-1289.

Laurino, D., Porporato, M., Patetta, A., \& Manino, A. (2011). Toxicity of neonicotinoid insecticides to honey bees: laboratory tests. Bulletin of Insectology, 64(1), 107-113.

Mahmoud, A. C. (2011). Effects of acetamiprid and glyphosate pesticides on testis and serum testosterone level in male mice. Journal of Duhok University, 14(1), 299-306.

Mansour, S. A., \& Mossa, A. H. (2010). Oxidative damage, biochemical and histopathological alterations in rats exposed to chlorpyrifos and the antioxidant role of zinc. Journal of Pesticide Biochemistry and Physiology, 96, 14-23.

Misra, H. P., \& Fridovich, I. (1972). The generation of superoxide radical during the autoxidation of hemoglobin. The Journal of biological chemistry, 247, 6960-6962.

Mohamed, I. K., El-Naggara, A. Y., \& Amr, A. A. (2015). A novel methods for protective role against reproductive toxicity of carbofuran in male rats using palm pollen grains and vanadyl(II) folate as a new compound. Journal of Chemical and Pharmaceutical Research, 7(4), 1142-1148.

Mondal, S., Ghosh, R. C., Karnam, S. S., \& Purohit, K. (2014). Toxicopathological changes on Wistar rat after multiple exposures to acetamiprid. Veterinary World, 7(12), 1058-1065.
Mondal, S., Ghosh, R. C., Mate, M. S., \& Karmakar, D. B. (2009). Effect of subacute exposure of acetamiprid on organ toxicity and growth of wistar rat. Indian Journal of Animal Health, 48(2), 67-72.

Mooradian, A. D., Morley, J. E., \& Korenman, S. G. (1997). Biological actions of androgens. Endocrinology Review, 8, 128.

Mosbah, R., Djerrou, Z., \& Mantovani, A. (2017). Protective effects of Nigella sativa oil against acetamiprid induced reproductive toxicity in male rats. Drug and Chemical Toxicology, 3, 1-7.

Neave, N., \& O'Connor, D. B. (2009). Testosterone and male behaviours. The Psychologist, 22, 28-31.

Ngoula, F., Watcho, P., Dongmo, M., Kenfack, A., Kamtchouing, P., \& Tchoumboué, J. (2007). Effects of pyrimiphos-methyl (an organophosphate insecticide) on fertility of adult male rats. African Health Sciences, Pp. 3-9.

Nicolino, M., \& Forest, M. G. (2001). La puberté. In La reproduction chez les mammifères domestiques et chez I'homme.Thibault C, Levasseur MC (eds). INRA Editions, Pp. 655-679.

Nilsson, U. A., Olsson, L. I., Carlin, G., \& Bylund-Fellenius, A. C. (1989). Inhibition of lipid peroxidation by spin labels. The Journal of biological chemistry, 264, 11131-5.

Singer, P. L. (2005). Pathways to pregnancy and parturition. Cadmus professional communication, Second revised edition. Pp. 44-79.

Singh, T. B., Mukhopadhayay, S. K., Sar, T. K., \& Ganguly S. (2012). Induced Acetamiprid Toxicity in Mice: A Review. Journal of Drug Metabolism and Toxicology, 3(6), 1-2.

Sinha, A. K. (1972). Colorimetric assay of catalase. Analytical biochemistry, 47, 389-394.

Swan, S. H., Brazil, C., Drobnis, E. Z., Liu, F., Kruse, R. L., Hatch, M., Redmon, J. B., Wang, C., Overstreet, J. W., \& The Study for Future Families Research Group (2003). Geographic difference in serum quality of fertile U.S. males. Environmental Health Perspectives, 111(4), 414-420.

Tomizawa, M., \& Casida, J. E. (2005). Neonicotinoid insecticide toxicology: Mechanisms of selective action. Annual Review of Pharmacology and Toxicology, 45, 247-268.

Turkyilmaz, U. B., \& Dereboylu, A. E. (2015). Some physiological effects of acetamiprid on two cultivars of corn plants. International Journal of Experimental Botany, 84, 144-147.

Umar, H. A., Eze, E. D., Ahmed, L., Isa, A. S., \& Ibrahim, S. M. (2012). Endosulfan-induced changes in sperm count, testicular weight and some erythrocyte indices in male guinea pigs. British Journal of Pharmacology and Toxicology, 3(4), 151155.

Wang, C., Swerdloff, R. S. \& Iranmanesh, A. (2000). Transdermal testosterone gel improves sexual function, mood, muscle strength, and body composition in hypogonadal men. Journal of Clinical Endocrinology and Metabolism, 85, 2839-2853.

Zhang, J., Wang, H., Xiang, M., Li, L., Li, K., Ma, X., \& Wang, X.Z. (2011). Oxidative stress: Role in acetamiprid-induced impairment of the male mice reproductive system. Agricultural Sciences in China, Pp.786-796. 